\title{
The Triumph of Religious Education for Citizenship in English Schools,
} 1935-1949'

\section{Rob Freathy}

\begin{abstract}
The failure of the Association for Education in Citizenship to gain official support for the secular and pedagogically progressive forms of education for citizenship which its founder members endorsed has previously been explained by the political impotence of the association's founder members and the professional conservatism of the educational establishment. However, this paper proposes that, as part of a wider cultural conservatism in England between 1935 and 1949, citizenship was recast in a Christian mould in response to foreign 'secular' political ideologies and that this enabled religious education to gain official endorsement as an essential form of education for citizenship.
\end{abstract}

\section{Introduction}

Between 1935 and 1949 there were many notable developments in regard to religious education and education for citizenship in English schools, such as the creation of Local Education Authority (LEA) Agreed Syllabuses for Religious Instruction, the publication of the journal Religion in Education Quarterly from 1934, the foundation of the Institute of Christian Education at Home and Abroad in 1935, the launch of the Association for Education in Citizenship in 1935, and the articulation of 'official' responses to these developments in numerous reports (e.g. Spens, 1938 and Norwood, 1943) ${ }^{2}$ and in the 1944 Education Act. However, the historiography of the curriculum subject called 'religious education' often neglects to look at religious education in the decades immediately prior to the 1944 Education Act, despite the fact that many of this 
Act's central components regarding the relationship between religion and schooling were developed in, or arose from, the context of the 1920s and 1930s. ${ }^{3}$ In addition, although education for citizenship in this period was influenced by the common belief that English national identity and political traditions have Christian foundations, the historiography of education for citizenship often neglects to provide a detailed analysis of Christian perspectives and frequently treats them as archaic precursors to 'real' secular versions of education for citizenship which emerged later. ${ }^{4}$ In such accounts, the history of education for citizenship is presented as an inevitable progression from religious education for subjecthood of monarch and church, on the one hand, to political education for citizenship of a secular, liberal and democratic state, on the other. Through an analysis of an indicative range of primary sources, such as Board of Education reports, academic and professional journal articles, books and pamphlets, this paper seeks to redress the balance by drawing attention to the ongoing contestation between religious and secular theories of education for citizenship between 1935 and 1949, and by examining the importance and influence of Christian conceptualisations of education for citizenship. Thereby it contributes to the historiographical traditions relating to both religious education (see Dennis Bates, Cathy Michell and Terence Copley) ${ }^{5}$ and education for citizenship (see Guy Whitmarsh, Derek Heater and Jessie Wong). ${ }^{6}$ In the following sections, the paper describes the nature and purpose of the Association for Education in Citizenship and how these have been understood by historians, analyses Christian conceptualisations of education for citizenship that have been neglected in the historical literature, and discusses how religious education for citizenship came to gain official endorsement in the 1940s.

\section{Education for Citizenship}

Acts of political reform in the $19^{\text {th }}$ century ensured that a growing proportion of the English population was granted political rights and responsibilities. This seems to have provoked an interest in how to prepare children for citizenship. 
Previously, it had generally been assumed that the churches provided a form of spiritual and moral education for citizenship through religious education. However, this assumption appears to have been challenged by state secularisation, the reduced influence of the Church of England, the development of non-denominational board schools, the creation of secular educational philosophies, and a growing concern for secular ethical instruction (for example, the Moral Instruction League, 1897-1919). ${ }^{7}$ Subsequently, new forms of education for citizenship developed outside of the churches' control, although rarely outside of a Christian moral framework. In elementary schools, these often consisted of explicit and direct teaching through school activities, such as Empire Day, or through curriculum subjects like Geography, History and Civics. ${ }^{8}$ The latter did not flourish: schools were commonly expected to be apolitical. ${ }^{9}$ In secondary schools, education for citizenship (or leadership) largely became associated with public school traditions inspired by Thomas Arnold's ${ }^{10}$ Rugby School. These traditions aimed to nurture pupils into 'Christian gentlemen' through implicit and indirect methods within a whole school Christian ethos. ${ }^{11}$ As Patrick Brindle and Madeleine Arnot have noted, education for citizenship 'was predicated upon the ideal citizen as the active, publicly and professionally defined, male' which is why the great majority of citizenship education textbooks excluded 'discussions of the private sphere and women from the legitimate frame of political enquiry'. ${ }^{12}$

It is generally agreed that from the late $19^{\text {th }}$ century to the first decades of the $20^{\text {th }}$ century, education for citizenship was mainly based on politically and religiously conservative conceptions of English national identity. By and large, these were defined in terms of Anglo-Saxon origins, the English language, the British Isles and Empire, Whig history, white skin, Christian fellowship and the loyalty and passivity of subjecthood. They were also often shaped by powerful contemporary discourses about Social Darwinism, racial superiority, imperialism and militarism. The existence of the Empire was commonly a source of pride and it was often interpreted as proof of Britain's superiority over other nations. However, after the First World War, the League of Nations Union 
promoted a new form of education for citizenship which advocated internationalism and peace rather than imperialism and militarism. ${ }^{13}$ Another powerful contemporary discourse which affected many conceptions of national identity related to Idealist notions of the 'organic' society under the influence of T. H. Green. ${ }^{14}$ He had argued that individuals find fulfilment through public service in the organic, corporate and spiritual community of the state. This idea seems to have resonated with a wider middle-class yearning to re-establish an organic society modelled on the co-operative and communal organisation of an idealised medieval village where the hierarchically ordered folk lived in harmony.

According to Kevin Myers, the traditional conceptions of national identity noted above were challenged in the interwar period by a more dynamic definition of citizenship. This promoted active membership of the national community, the assertion of political rights and social and moral responsibilities, and a belief in the socially cohesive power of a secular and gentle patriotism which is accessible, rational, active and committed to parliamentary government, political pluralism and humane values. It was championed by leftwing liberals and social progressives. Furthermore, this expansive definition of English citizenship was translated into educational theory by Ernest Simon and Eva Hubback who founded the Association for Education in Citizenship (AEC) in 1935. ${ }^{15}$ The AEC was a national organisation which boasted an impressive executive council of mostly progressive intellectuals and well-known educationalists. It sought to promote training for citizenship in schools through various means, such as conferences, publications, local branches, a journal called The Citizen (1936-1939), as well as through pressure group activity. Its founder, Ernest Simon, ${ }^{16}$ was a Mancunian industrialist who had a distinguished career in local and national government for the Liberal Party. After he lost his parliamentary seat in the 1931 General Election, he became concerned by the nation's economic difficulties, the rise of Fascism and anti-Semitism and the widespread loss of confidence in parliamentary government. ${ }^{17} \mathrm{He}$ also became preoccupied with the idea that the education system should create and sustain 
political loyalties, social control and confidence in the political system. ${ }^{18}$ These goals were sought in collaboration with his friend Eva Hubback ${ }^{19}$ and his wife Shena D. Simon. ${ }^{20}$

In contrast to the well-known biographical details cited above, historians of education for citizenship, like Guy Whitmarsh and Derek Heater, have paid little attention to the 'humanist agnosticism' which led Ernest Simon to analyse his character and achievements in multiple diary entries and to define his religion as the desire to leave the world a better place by doing good to others. ${ }^{21}$ Yet such knowledge helps to interpret the primary sources containing his political and educational theories and to relate them to other theories, policies and practices of the time. In 'The Faith of a Democrat' (1937), Simon argued that democracy can only be defended against undemocratic political ideologies by the powers of common sense, co-operation and good will which are developed through 'long, practical experience of responsibility in selfgovernment' and 'the gradual acquirement of tolerance and wisdom' through 'full and free discussion of all aspects of public affairs' ${ }^{22}$ Furthermore, in contrast to many of his contemporaries, Simon argued that religion cannot defend democracy because it is at the mercy of falsehood and of being reduced to mythology. ${ }^{23}$ For him, a philosophical desire to do what is right, to know the truth and to desire beauty for its own sake, is the only thing that can produce a democratic state. Thus, he argued that it is essential to train people for their duties as citizens so as to protect democracy from the challenges posed by press lords and dictators. ${ }^{24}$ These theories, along with the agnosticism and utilitarian ethics which underpinned them, also seem to have been shared by Eva Hubback (co-founder of the AEC) despite her Orthodox Jewish roots. ${ }^{25}$ When combined with a lack of confidence in conventional means of preparing pupils for citizenship through traditional subjects and a whole school Christian ethos, they led Simon and Hubback to advocate (i) direct and specific 'training in the moral qualities necessary for the citizens of a democracy' which recognises that citizens have an imperative duty to help their fellows and to relieve suffering, regardless of what they believe about ultimate reality, (ii) 
'clear thinking in everyday affairs' through scientific methods, and (iii) 'the acquisition of that knowledge of the modern world usually given by means of courses in history, geography, economics, citizenship and public affairs' ${ }^{26}$

In his thorough examination of the politics of education relating to the AEC, Guy Whitmarsh has illustrated the impotence of the association as a pressure group and the conservatism of the Board of Education and the Consultative Committee in relation to, firstly, the 1938 report of the Consultative Committee ${ }^{27}$ under the chairmanship of Will Spens, ${ }^{28}$ secondly, the manner in which Stanley Baldwin ${ }^{29}$ tried to use his position as the AEC's president to keep party politics and political bias out of schools, and thirdly, the 1943 report of the sub-committee of the Secondary School Examinations Council under the chairmanship of Sir Cyril Norwood ${ }^{30}$ which advocated the incidental teaching of citizenship through ordinary subjects and the general life and Christian spirit of schools. ${ }^{31}$ More recently, Kevin Myers has interpreted Norwood's 'ethereal, spiritual and traditional sense of citizenship' as evidence of how educational constructions of English citizenship and national identity were increasingly couched in explicitly Christian terms by an education establishment which utilised the international crisis and the contemporary emphasis upon England's Christian tradition to fashion policy in a conservative manner. ${ }^{32}$ In this context, it is perhaps unsurprising that neither the 1943 White Paper Educational Reconstruction nor the subsequent Education Bill (May 1944) advocated the introduction of direct education for citizenship into schools. Instead, the preparation of young people for the responsibilities of citizenship was to be limited to the compulsory, part-time further education of 15 to 18 year olds in LEA County Colleges, as discussed in the Ministry of Education's Pamphlet 3: Youth's Opportunity: Further Education in County Colleges (1946). ${ }^{33}$ However, by interpreting the involvement of the Christian churches and Christian educationalists as merely impediments to beneficial educational reform, historians of education for citizenship may have unduly diminished the cultural, political and educational importance of Christianity at a particular time of national upheaval relating to the General Strike (1926), mass 
unemployment, the rise of Communism, Fascism and Nazism abroad, the Abdication crisis (1936), the influx of refugees and the Second World War (1939-45). Furthermore, perhaps because of their own research preferences,

philosophical assumptions or the more secular context in which they write, historians of education for citizenship have neglected to relate their research to the precise nature and purpose of Christian perspectives on education for citizenship or to evaluate the extent to which the discourses relating to religious education and education for citizenship ran in parallel, in opposition or overlapped. The following sections address these issues.

\section{Conviction Politics and Religious Education}

According to Matthew Grimley, the Church of England sought to justify its Established status in the interwar period through an offensive in socio-political spheres which was predicated on the basis that the Church acts as the agent of the common Christianity upon which the national community is founded. ${ }^{34}$ Prominent politicians, like Stanley Baldwin, also defended Church Establishment as a means of safeguarding political cohesion and public morality from the challenges posed by universal suffrage, class interest and the Abdication crisis (1936). Furthermore, as Phillip Williamson has argued, Baldwin believed that the secularism, materialism and state worship found in totalitarian states on mainland Europe should be countered by Christian values. ${ }^{35}$ Indeed, there is some evidence to suggest that English culture was partially re-Christianised, such as the increase in Church and Sunday School attendance and the vast congregations that attended countrywide Services of Intercession. ${ }^{36}$ This cultural change may have been the result of the Anglican offensive in socio-political spheres, the rise of totalitarianism abroad, the onset of the Second World War and/or an ecumenical Christian revival. The latter was led by William Temple ${ }^{37}$ and the tranche of intellectual Christian statesmen who contributed to the Moot seminar group, The Christian News-letter and the Christian Frontier Council. ${ }^{38}$ Accordingly, many politicians, churchmen and writers interpreted the war as a fight between belligerent, secular and 
materialistic dark forces, on the one hand, and the Christian moral values upon which English freedom, justice and democracy are founded, on the other. ${ }^{39}$ In this context, it is possible to suggest that the founder members of the AEC failed to influence the Board of Education, the Consultative Committee and the Secondary School Examinations Council not merely because the AEC was politically impotent and the educational establishment was professionally conservative. A more fundamental and pervasive cultural conservatism may have ensured that the secular basis of education for citizenship promoted by the founder members of the AEC was out of kilter with the widely held view that English citizenship is founded on Christian morals and values. This possibility will be explored with reference to the conceptualisations of citizenship and education for citizenship proposed by the churchmen and Christian educationalists who contributed to the public discourse relating to religious education in English schools between 1935 and 1949.

In a comprehensive sense, 'religious education' refers to the transmission of religious beliefs and values through the educational process as a whole. ${ }^{40}$ In a curricular sense, it pertains to education in religion in the form of a subject (e.g. Religious Instruction). However, the definition of religious education and Religious Instruction in England between 1935 and 1949 is complicated by the dual system of church and state schools. In Anglican and Roman Catholic schools, denominational religious education and instruction were usually used to create a school atmosphere conducive to church membership. By contrast, in LEA schools, religious education pertained to a non-denominational form of Christianity and Religious Instruction which was limited to Bible reading, the Ten Commandments and the Lord's Prayer. ${ }^{41}$ While most secularists and Nonconformists opposed denominational religious education, the majority of Anglicans and Roman Catholics opposed non-denominational Christian education. To placate the Anglican Church, some LEAs introduced a form of compulsory Religious Instruction defined jointly by Anglicans, Nonconformists, LEAs and teachers (e.g. County Council of the West Riding of Yorkshire: Education Department Syllabus of Religious Instruction, 1922). Dennis Bates 
believes that these 'Agreed Syllabuses' helped religious education and instruction in LEA schools to professionalize on the basis of a 'religio-idealistic' rationale which promoted an ecumenical understanding of religion. ${ }^{42}$

Furthermore, according to Cathy Michell, Christian educationalists in this tradition frequently called upon schools to transmit the Christian essence of English national identity and to train citizens for the Kingdom of God. ${ }^{43}$ Therefore, while the majority of Anglican schools sought to enable the Church of England to maintain its traditional hold over the nation's moral values and to initiate citizens into the Christian community of which it believed it was the foremost representative, religio-idealistic Christian educationalists sought to promote loyalty to the non-specific Christian culture which the majority of the populace seem to have believed undergirded national identity and democratic ways of life. In contrast, Roman Catholic education tended to prioritise denominational membership.

\section{Religious Education and the AEC}

Dennis Bates defines the period between $c 1920-c 1960$ as an 'Ideological Period' of religious education because its nature and purpose changed in response to secular ideological developments. ${ }^{44}$ However, like other historians of religious education, such as Cathy Michell and Terence Copley, Bates does not relate the changing theories and practices of religious educators to the sometimes parallel, opposing and overlapping curricular and pedagogical discourses of other communities, such as the AEC. Yet the wider educational interest in preparing children for citizenship during the interwar period provides a valuable vantage point from which to interpret religious educationalists' responses to the secular ideological developments which Bates mentions. For instance, J. H. Oldham was one of the foremost influences in steering the minds of religious educationalists to think about the threat of secular ideologies. $\mathrm{He}$ desired to make Christianity the unifying and inspiring focus of English society, democracy and education. Thus, in Christian Education: Its Meaning and Its Mission (1931), he criticised secular humanism for being inimical to social 
values and cohesion and for leading to an increased sense of aimlessness, meaninglessness and despair. ${ }^{45}$ Later, he sought to defend Christianity from the rival faiths of Nationalism, Soviet Communism and Internationalism which respectively promoted personal sacrifice to the state, economic salvation and the establishment of one secular dogmatic world state. ${ }^{46}$ For Oldham, these rival faiths could only be overcome by an essentially relational and passionate conception of ecumenical Christianity that preaches social justice and draws its strength from something higher than human ideals. ${ }^{47}$ In terms of education, he rejected individual and liberal philosophies on the basis that they lack direction and purpose and are easily overtaken by autocratic ideologies. Instead, he wished education to be a process in which children are initiated into the Christian life through the experience of living, worshipping and learning in schools which are Christian communities ${ }^{48}$ He stated that, '[the] ordinary classes, work in the fields, games, the common life of the school and relations with the larger community outside, all furnish opportunities of learning what it means to be a Christian in the actual relationships of life' and that '[this] conception of religious education restores the connection between religion and life'. ${ }^{49}$ For him, a Christian school would exemplify truth in community through which pupils develop a sense of social justice and service leading towards knowledge of God. ${ }^{50}$ Thus, the preparation of pupils for Christian citizenship seems to have been one of the aims which Oldham afforded to English schools.

Like Oldham, many contributors to the professional journal for religious educators - Religion in Education Quarterly - also evidenced increasing unease caused by secularisation at home, the rise of antagonistic ideologies abroad and the threat of war. Also, like him, they agreed that English traditions and values could only be defended by the bastion of Christianity. In the first issue, Lord Irwin $^{51}$ signalled the Board's approval for the role of religious education in perpetuating English moral values and character in the face of hostile ideological forces. ${ }^{52}$ Furthermore, the journal's first editor - Basil Yeaxlee ${ }^{53}$ called upon the 'children of light' to demand that all educational institutions, homes, churches, cities and recreation should be 'in conformity with the mind of 
Christ' because only the English tradition of Christian values can thwart secularism and paganism. ${ }^{54}$ From this, and other examples, ${ }^{55}$ it is possible to suggest that as wider society increasingly promoted Christianity as the bulwark of English national identity and political traditions, so various Christian educationalists recast religious education into an essential form of education for citizenship. Moreover, such a view was not limited to participants in the religious education discourse. Many educationalists who were affiliated to the AEC also claimed that education for citizenship should have a religious basis and that religious education was the best means of educating pupils for citizenship. In this manner, the secular and pedagogically progressive proposals of the founder members of the AEC were not only challenged by external opponents, but also undermined from within by the philosophical inclinations of its own members. This supports Patrick Brindle and Madeleine Arnot's argument that 'one of the reasons why there is no tradition of teaching citizenship in English state schools is that no group has succeeded in constructing a consensus over the question of what is education for citizenship'. ${ }^{56}$

The first example of a religious conception of education for citizenship promoted under the auspices of the AEC is derived from its Bryanston School conference in 1937. The conference had been convened to pool ideas and experiences of Experiments in Practical Training for Citizenship. The Headmaster of Bryanston - Thorold F. Coade ${ }^{57}$ - argued that a religious basis was lacking in English attempts to arouse that spirit of self-sacrifice which was so obviously alive in totalitarian states. As a result, he called for 'the allembracing principles of the real original Christianity of Jesus' to underpin good citizenship in contrast to 'the exclusive neurotic race-consciousness of Fascism or the fanatic materialistic class-consciousness of Communism'. ${ }^{58}$ Thus, the new form of education for citizenship which he proposed was in opposition to previous forms predicated on the basis of Social Darwinism and racial superiority, as well as in opposition to the secular, liberal form promoted by Simon and Hubback. Coade saw in the examples of education for citizenship 
presented at the AEC conference 'a great deal of the same spirit that animates real Christianity' and which can be used to kindle a new enthusiasm for good citizenship. ${ }^{59}$ His statement reflects his own personal background as the son of a vicar, as well as the Christian foundation of Bryanston School, but it also addressed a specific question raised by Ernest Simon at the start of the conference. Clearly, the two men could co-operate in the promotion of education for citizenship, but they disagreed about the philosophical foundations underpinning it. Such a tension was also evident when E. Addison Phillips ${ }^{60}$ criticised the AEC's Education for Citizenship in Secondary Schools (1935) on the basis that it failed to mention Religious Instruction. She argued that the ideal of the brotherhood of humankind is not easy to maintain without belief in the 'fatherhood of God, the creator and lover of every individual soul' ${ }^{61}$ Moreover, she stated that the difficulty presented by all the clashing loyalties and divergent aims of life could be avoided, if they were caught up into one supreme loyalty and all-embracing purpose provided by faith in God and the desire to serve him through civic duty. Therefore, she called upon religious education to provide the motivation and character needed to develop a sense of citizenship. ${ }^{62}$

The AEC's Education for Citizenship in Elementary Schools (1939) was more positive towards religious education. This may have been due to the criticism above, the qualitative distinction between elementary and secondary education, the selection of authors or the growing receptiveness towards religious conceptions of citizenship. A. Leslie Hutchinson ${ }^{63}$ provided evidence for the latter interpretation in a chapter entitled 'The Aims for Education in Citizenship'. Hutchinson argued that attitudes towards religion had changed as a result of a growing understanding that good citizenship depends on religious ethics and that there was a general belief that one of the principal aims of religious education is to foster the growth in social conscience which undergirds good citizenship. For him, this was particularly important because the defeat of rival political philosophies would depend on all members of the community understanding the spiritual and social values on which their society 
is based. ${ }^{64}$ Such themes were also taken up in a chapter by C. T. Cumberbirch ${ }^{65}$ who focused on how Religious Instruction could develop the spiritual and moral qualities of citizenship by emphasising religious ethics grounded on 'the transcendent Will, Authority and Love of God' rather than humanist ethics focused on state law and human morality as ends in themselves. Cumberbirch argued that Religious Instructors can provide education for citizenship, so long as they are interested in the social implications of Christianity and the way in which human problems can be considered in the light of the love of God and the love of one's neighbour. As an example, she urged teachers to present Jesus 'in the actual circumstance of time and place, in busy towns', 'in touch with ordinary people' and 'amidst the crowds of different races, sects and classes among whom there is political, racial, social and religious hostility'. She maintained that this would add a startling force to Jesus' life and message such that it would be able to 'command the loyal devotion of youth' ${ }^{66}$ The chapter also called for religion to pervade the entire curriculum in such a way that 'religion is the only subject taught and the only subject lived' ${ }^{67}$ For Cumberbirch, this pervasive religious training would encompass citizenship training as both theories of religion and citizenship are lived out in practice through the school life and curriculum and the school's links with the community outside.

These examples of religious education for citizenship are important because they indicate the extent to which Christianity continued to be seen as the provider of the ethical foundation for citizenship. They also supply evidence that the conception of secular and pedagogically progressive education for citizenship promoted by the founder members of the AEC was opposed not only on the grounds of political and educational conservatism, but also on the grounds of a religious conservatism which has been previously downplayed by historians of education. Furthermore, this religious conservatism came from leading members of the AEC, such as Spencer Leeson, ${ }^{68}$ who was the most vociferous advocate of a form of education for citizenship based on, what Guy Whitmarsh has called, 'the elaboration of the school as a benevolent 
hierarchical social system whose ethical values were anchored in formal religion'. ${ }^{69}$ Leeson was positive towards the idea that schools should train children in good citizenship. ${ }^{70}$ Moreover, he pledged his commitment to 'the English political and educational tradition' which would train pupils to enquire and make judgements on politics in an atmosphere conducive to freedom of thought, discussion, tolerance, responsibility and reverence for the law.

However, he placed greater emphasis on moral responsibilities and noted that, Some will approach the task in the temper of the humanist, for the service of man as man, the last and most splendid term in the series of creation: others, of whom I am one, in the temper of those to whom Christ's command is everything. [...] We are all children of one Father, brothers and sisters in one family where Christ is the eldest brother. And as our minds dwell on this thought, the horizons of our citizenship enlarge beyond the bounds of one country and one commonwealth. Our citizenship is in Heaven. ${ }^{71}$

As a result, Leeson believed that citizenship could only be a secondary aim of education because the primary aim should be to attain knowledge of God as the Father of humankind and to love him and do his will. ${ }^{72}$ In this context, he argued that spiritual incorporation into the life of a community through citizenship merely points forward to life in God and promotes rich, balanced and moral growth. ${ }^{73}$ Furthermore, he maintained that only a Christian state can justify the fulfilment of civic duties and provide political security. ${ }^{74}$ He held that '[t]he State that does not look to God is a bastard and no son: it is not really a State at all, and however imposing its outward façade, it will never bring lasting satisfaction to the soul or claim its full allegiance' ${ }^{75}$ Perhaps this is why he was keen to encourage the Church and educational institutions to protect the Christian foundations of English national life. In terms of schools, Leeson only advocated direct instruction regarding social and political issues in Sixth Form lessons on Classics and History, ${ }^{76}$ otherwise he argued that education for citizenship should be undertaken by means of the public school tradition in which Christianity permeates the whole life and work of the community and gives it character, unity and a directing purpose. For him, religious education, 
education for citizenship and character training were synonymous in the same way that being a good Christian, a good citizen and a good human were held to be identical. Thus, he could state that a 'good Christian must necessarily be a good citizen' and that if 'a so-called scheme of Christian education does not create good citizens, it cannot claim to be either Christian or education' ${ }^{77}$

\section{Christian Education in the Second World War}

During the Second World War, numerous prominent educationalists rejected secular theories of education and promoted religious education as a means of preparing pupils for citizenship and defending Britain's moral values and liberal democratic traditions. ${ }^{78} \mathrm{M}$. V. C. Jeffreys ${ }^{79}$ argued that only Christianity is able to induce citizenly love as a matter of divine obligation rather than social utility and to provide parliamentary democracy with a common faith powerful enough to balance the conflicting claims of individualism and totalitarianism by upholding the infinite value of the individual and the ethical demands of society. ${ }^{80}$ He stated:

... it is of the utmost importance to realise that, although essentially idolatrous, totalitarianism has the real power of common effort, common suffering and common faith. That is why no effective answer to totalitarianism can come from traditional liberalism and why - for all our talk about this war being a war of ideas - our enemies with their wicked ideas, may be stronger than we, if we have no ideas at all! We must oppose faith with faith, bad religion with good religion. ${ }^{81}$

Thus, he called for the Christianisation of schools which would include: an interchange between school and society, as evident in religious education; the Christianisation of the curriculum including a religious form of Social Studies; and an acceptance of the modern world in a way which did not replace the Kingdom of God with 'a mildly optimistic humanism trailing the faded rags of a theological fancy dress' ${ }^{82}$ Other proponents of Christian education for citizenship included Marjorie Reeves, ${ }^{83}$ who argued that pupils should be consciously inducted into citizenship of Christian schools in order to develop a 
fanatical enthusiasm for Christianity comparable to that exhibited by German citizens for Nazism, ${ }^{84}$ and Fred Clarke, who sought to resolve the tension between individualism and communitarianism by calling upon the education system to embrace personal freedom and diversity within a synthetic Christian philosophy. ${ }^{85}$ Conversely, Maurice Jacks ${ }^{86}$ contrasted Christian education and education for citizenship by arguing that a total Christian education would enable a child to 'be treated as a whole person here and now' rather than as 'an embryonic adult' and that education would not mean 'a preparation for something else (for 'earning a living' or for 'citizenship', or for 'life' or some equally vague and distant end), but the provision of a wholly satisfying life today' ${ }^{87}$ Similarly, in another resolute defence of Christian education, the Rev. J. M. Lloyd Thomas ${ }^{88}$ argued that if 'schools are expected to train children to be 'good citizens', it should be recognised that this means much more and other than an education in the outward acts and secularities of the social and political life, especially in a State that by its very constitution professes to be a Christian State'. ${ }^{89}$ He maintained that a national education system in a Christian country must have a Christian ethical character and that materialists, rationalists and secularists who seek to replace religious education with education for citizenship are guilty of slurring over the intensely different conceptions of good citizenship held by Christians, Fascists, Socialists and Communists. ${ }^{90}$ Consequently, Lloyd Thomas called for an understanding of the varying ideals of social, political and economic well-being including the religious ideal of Civitas Dei.

In addition to the above, an abundance of articles in Religion in Education Quarterly during the Second World War bear witness to the increasing confidence with which a host of Christian educationalists asserted the Christian origins of democracy and citizenship. Firstly, E. L. Allen ${ }^{91}$ advocated theological reflection on the nature of democracy to inculcate an understanding of its Christian and biblical roots and to counter the 'stark, strident dictatorships' which had highlighted its fragile and uncertain nature. ${ }^{92}$ Secondly, Canon Dr. S. P. T. Prideaux ${ }^{93}$ argued that the Bible, particularly the New Testament, provides 
a handbook for the teaching of citizenship because citizenship is the art of living together in the light of the primacy of God who governs, inspires and directs all human activities and relationships. ${ }^{94}$ Thirdly, Cyril Bailey ${ }^{95}$ called for social and educational divisions to be dissolved by Christian justice, freedom and understanding and for this to be achieved through the establishment of a Christian democracy ${ }^{96}$ Fourthly, Hugh Lyon ${ }^{97}$ stated that, in contrast to 'Humanistic' philosophies which do not contain enough potency to overthrow the selfish or material interests of the fanatical patriot, Christianity can supply the spiritual foundation for world citizenship because it provides driving power, righteous indignation, overriding motivation and sure ground for hope. ${ }^{98}$ Lastly, Maxwell Garnett ${ }^{99}$ advocated international educational planning to facilitate the integration of all world citizens and to advance the establishment of the Kingdom of God on earth. ${ }^{100}$ The idea was based on a belief that the war had produced a quasi-religious bond between individuals which would cease unless a Commonwealth of United Nations was established to promote loyalty towards God and towards each individual on the basis of their connection to him. ${ }^{101}$ Thus, Garnett stated, 'there is no reason why the schools of Christian England should not be seeking to make Christians with the same unanimity and fervour that is shown by the schools of Nazi Germany in their effort to create Nazis'. ${ }^{102}$

Overall, these sources suggest that there was a widespread belief that English social and political traditions, including freedom, justice and democracy, would only endure if national religious traditions, values and morality were supported. Moreover, the growing acceptance among the populace of the need for spiritual principles to underpin national life appears to have presented an apposite opportunity for churchmen and Christian educationalists to persuade the Board of Education, the Consultative Committee, the Secondary School Examinations Council and the wider educational establishment that the state sector of education should preserve and foster democratic ideals and Christian moral values by accepting a conservative form of education for citizenship which was indistinguishable from Arnoldian public school traditions in which the entire life and curricula of schools was inspired, integrated and pervaded by 
ecumenical, liberal Protestantism. Arnoldian traditions would have been very familiar to educationalists in the first half of the twentieth century because of the widespread means by which they were disseminated. For example, in 1901 the Board of Education presented every teacher trainee in England and Wales with a new single volume edition of A. P. Stanley's Life and Correspondence of Thomas Arnold DD (1844). In the preface, Sir Joshua Fitch ${ }^{103}$ stated that Arnold's career illustrated how a schoolmaster should connect himself with the politics, religion, literature and corporate life of the community. ${ }^{104}$ Furthermore, in the 1930s and 1940s, Arnold became re-incorporated into the idea of 'Englishness' as evidenced by Robert Stevenson's 1940 and Gordon Parry's 1951 film versions of Thomas Hughes' ${ }^{\prime 105}$ Tom Brown's Schooldays (1857) in which the promotion of physicality, fair play, boldness, a fighting spirit, sociability and Christian morality all chimed with British wartime propaganda.

\section{Political Conservatism and Religious Education}

There is evidence to suggest that the Christian educationalists' campaign received a positive response from the Board of Education, the Consultative Committee, the Secondary School Examinations Council and the wider educational establishment. ${ }^{106}$ The Spens Report (1938) placed religious education and worship at the forefront of the curricula and daily life of schools. ${ }^{107}$ Moreover, it commended Agreed Syllabuses, Lord Irwin's Board of Education conference on the training of Religious Instruction teachers ${ }^{108}$ and the Institute of Christian Education at Home and Abroad. It concluded that no person should be counted as properly educated unless they have been made aware of 'the existence of a religious interpretation of life'. ${ }^{109}$ In addition, the Norwood Report (1943) called for Religious Instruction to be taught by form masters whose interest and desire proceeds from religious faith and for this exemplification of Christian purpose to unify the curriculum and pupils' personalities. Furthermore, it called for a greater number of teachers to be qualified to teach Religious Instruction and for Religious Instruction to be taught in not less than the two periods a week. This was designed to ensure that 
schools made up for the deficiencies of homes and churches by introducing pupils to the Christian interpretation of life and Christian ethical standards. ${ }^{110}$

In this re-Christianising context, it is perhaps not surprising, as Charmain Cannon has noted, that contributions to the parliamentary debates regarding the White Paper Educational Reconstruction and the Education Bill (1943-1944) generally held that the nation's future and the prevention of war depend upon the ability of schools to arrest and reverse religious decline, as was the wish of the majority of people, even if they did not attend church. ${ }^{111}$ This provoked much discussion pertaining to religious education and the dual system, but also stimulated interest in education for citizenship and the need to develop within pupils a readiness to put social service ahead of selfish goals. The resultant Education Act (1944) made LEAs responsible for contributing to the spiritual, moral, mental and physical development of the community, implying that spiritual development was the first aim of education. ${ }^{112}$ The Act also reformed the dual system by creating county, voluntary controlled, voluntary aided and special agreement schools and stated that every county and voluntary school should provide a daily act of collective worship and weekly Religious Instruction, except in the case of pupils who are withdrawn by their parents. Support for church schools and religious education was partly due to the economic or political prudence of placating the churches to expedite educational reform, but it may also have reflected the religiosity of the time. Many Christian educationalists interpreted these new statutory requirements as evidence that the state had rejected a neutral position with respect to the place of religion in society, in favour of fulfilling the 'people's wish to reaffirm their nation's essential Christian character' as the first step towards world salvation. ${ }^{113}$ After the war, many LEAs produced Agreed Syllabuses which embodied the desire of Christian educationalists to establish a Christian social order. They sought to show pupils the right relationship between God and humankind and to train them to become Christian citizens through courses in Christian civics. Some promoted comprehensive forms of religious education in which the entire school would become a training ground in Christian 
citizenship. ${ }^{114}$ Thus, as Kevin Myers has argued, the conception of English citizenship promoted by the founder members of the AEC - as an accessible form of belonging based on democratic and humane values rather than religion - was superseded in formal policy by a conservative desire to make both the dominant form of communal gathering in schools and the only compulsory curriculum subject attestations of Christianity as the national faith. ${ }^{115}$

After the war, the AEC continued to engage in public debates regarding curriculum change through The Content of Education (1945), Democracy in School Life (1947) and Sixth Form Citizen (1950). However, in addition to the re-Christianisation and cultural conservatism noted above, 'the 1940s and 1950s were most unlikely to witness successful calls for more formalised instruction in citizenship and politics because of their association with the curricularised and propagandist methods of Nazi Germany and Stalinist Russia'. ${ }^{116}$ Nevertheless, many of the AEC's concerns were shared by official publications, such as the Ministry of Education Pamphlet No. 9. The New Secondary Education (1947) and the Central Advisory Council for Education in England's School and Life (1947). These were indicative of a post-war ethic which, according to Roy Lowe, emphasised the benign influence of formal education as a means of morally regenerating the nation. ${ }^{117}$ It was in this climate that the Ministry of Education published Pamphlet No. 16: Citizens Growing Up (1949) which directly addressed the moral bearings of society and the extent to which schools are the guardians of the nation's standards. ${ }^{118}$ Overall, Citizens Growing Up sought to promote the social, spiritual and moral emphasis of the traditional Arnoldian form of education for citizenship in contrast to the specifically secular, political and pedagogically progressive conception promoted by the founder members of the AEC from the mid-1930s.

First, Christianity was accepted as the basis of moral education and the democratic way of life. ${ }^{119}$ The pamphlet argued that spiritual convictions are vital because democracy must be defended by reasons stronger than political or social expediency. Thus, it held that Christians should play their part in forming the good society on the basis that they concern themselves with social duties, 
exalt the dignity of human personality, emphasise human fraternity, and justify good works as God-given duties. By contrast, the pamphlet argued that secular conceptions of citizenship reject the most enduring civilising force in world history and that which provides the only commandment to offer any social programme a certain chance of success: 'Thou shalt love the Lord thy God with all thy heart and with all thy soul and with all thy strength and with all thy mind, and thy neighbour as thy self'. ${ }^{120}$ Consequently, Citizens Growing Up viewed those who reject both Christian beliefs and Christian ways of life as waging a full frontal assault upon civilisation on the basis that the 'evil gospels' of force, which were evident in international politics, could only be met 'by a faith as positive and confident as their own'. It argued that the strength which a religious conviction gives to a social conscience is not a reason for religion, but it is an effect and that 'a pamphlet on education and society is bound to stress the strength that comes from deep convictions about good and evil, about the nature of God, and about the nature and destiny of man'. ${ }^{121}$ Thus, Citizens Growing $U p$ has been interpreted as another episode in the history of education for citizenship that the founder members of the AEC failed to influence, in terms of their liberal, tolerant and inclusive version of national identity rather than one based on geographical, racial or religious inheritance. ${ }^{122}$

Second, in an explicit endorsement of indirect character training and public school traditions, Citizens Growing Up argued that the corporate life of the school is the best means of providing democratic social training and developing citizenly qualities. However, it was also clear that curriculum reform was needed to train pupils for social relationships and political participation and to provide them with 'new knowledge' associated with the practical needs of the contemporary world. In this regard, the pamphlet devoted a separate section to Religious Instruction and called upon the subject to relate biblical material to the moral and spiritual issues which pupils face in their daily lives. According to the pamphlet, it would thereby contribute a uniquely powerful emphasis on conscience, individual responsibility and service. In addition, the pamphlet highlighted corporate worship as a form of education for citizenship in that it 
provides opportunities for pupil participation and for the celebration of Christian and civic occasions. Direct instruction and skills-training in citizenship was only discussed in relation to further education provision in the County Colleges. $^{123}$

Finally, in the epilogue, an expansive definition of citizenship was justified on the basis that humans are individual private souls who have personal relationships with God and the universe that form the background against which the socio-political sphere must be considered. ${ }^{124}$ Consequently, the public and political purpose of education for citizenship, as defined in terms of the nation-state, was subordinated to a private and spiritual purpose defined in terms of humanity as a whole. This expansive definition and its educational implications cohered more closely with the discourse of Christian educationalists than it did with the theories of the founder members of the AEC. Perhaps unsurprisingly, the association declined rapidly from around this time until its termination in 1957.

\section{Conclusion}

An analysis of the public discourses relating to religious education and education for citizenship in English schools between 1935 and 1949 reveals an ongoing tension between differing conceptions of education for citizenship. On the one hand, many members of the educational establishment equated religious education and education for citizenship and maintained that they are best 'caught' from the entire ethos, life and curriculum of schools. In its ecumenical, liberal Protestant form, this conservative education for spiritual and moral citizenship gained increasing support from the Board of Education, the Consultative Committee and the Secondary School Examinations Council. On the other hand, the small number of liberal intellectuals who founded the AEC promoted a secular and pedagogically progressive form of education for citizenship through practical training and direct instruction, which would provide pupils with a motivation to assert their social and political rights responsibly, so as to govern themselves more actively and to uphold Britain's 
liberal, secular and rational political progress. From the evidence cited in this paper, it would appear that in England the Christian and traditional conceptions of education for citizenship triumphed in securing a position in the national education system in the 1940s over and against secular and pedagogically progressive forms. This demonstrates the veracity of Patrick Brindle and Madeleine Arnot's argument that each 'organisation that took up the cause of citizenship education was involved in battles over the nature of citizenship as a philosophical concept, as well as battles over the pedagogic shape of the subject for schools'. ${ }^{125}$

The AEC's failure to influence the Board of Education, the Consultative Committee and the Secondary School Examinations Council does not appear merely to be the result of the political impotence of the AEC and the professional conservatism of the educational establishment, as has been implied by Guy Whitmarsh. A broader cultural change seems to have occurred in which secular thinking was challenged in response to the rise of radical political ideologies abroad. Consequently, during the 1930s and 1940s, there are numerous examples of the political establishment using the traditional alliance of Christianity, national identity and citizenship as a means of defending English social and political traditions and values. Underlying this was the assumption that only Christianity was capable in England of providing the passionate devotion for national identity which Communists, Fascists and Nazis had aroused elsewhere. Moreover, it appeared that the Christian foundations of English national identity were supported by ecumenical progress and by the vigour with which the Anglican Church had been bearing witness to Christian principles in the socio-political, economic and educational spheres. Thus, the secular, rational and optimistic theories of the liberal progressives who founded the AEC seem to have been in discord with a wider political and cultural conservatism. In this context, churchmen and Christian educationalists made countless calls for English democratic traditions and citizenship to be supported by religious education and these received an increasingly positive response from the educational establishment. Education for citizenship became the 
rationale for religious education to the extent that neither could be conceived of without an ethical basis grounded in Christianity. The prevailing concern for religiously sanctioned social and moral traditions, rather than secular political values, thus led the Board of Education and the educational establishment to seek to maintain a Christian formulation of the English tradition of education and to transmit it through a comprehensive form of religious education in the Arnoldian tradition.

This historical perspective has contemporary relevance in terms of contextualising the comparatively late introduction of 'Citizenship' as a statutory part of the National Curriculum at key stages three and four (11-16 year olds) in England and Wales in 2002. ${ }^{126}$ In addition, it has particular relevance in terms of contextualising the apparent breakdown of many of 'the institutions and values which have traditionally underpinned society and encouraged social cohesion and stability,' which David Kerr believes has led to the renewed interest in education for citizenship in England over the last two decades. ${ }^{127}$ However, whilst Kerr acknowledges that there is 'no tradition of developing national allegiance or social cohesion through the political system and civic culture' in England, he does not consider the extent to which Christianity, and the Established Church more specifically, provided the institutions, symbols and values which underpinned English national identity. ${ }^{128}$ By synthesising and analysing the two previously separate historiographical traditions relating to religious education and education for citizenship, this paper challenges historians and educationalists to examine afresh the place of religion in the history of interwar politics and education. 
${ }^{1}$ The author would like to thank Professor William Richardson of the University of Exeter for reading and commenting on earlier drafts of this article.

${ }^{2}$ Board of Education Consultative Committee. Secondary Education With Special Reference to Grammar Schools and Technical High Schools. London: HMSO, 1938; Board of Education. Curriculum and Examinations in Secondary Schools. Report of the Committee of the Secondary School Examinations Council. London: HMSO, 1943.

${ }^{3}$ For example, Copley, T. D. Teaching Religion: Fifty Years of Religious Education in England and Wales. Exeter: University of Exeter Press, 1997 and Wedderspoon, A. G. (Ed.) Religious Education 1944-1988. London: Allen and Unwin, 1966.

${ }^{4}$ Lambert, D., and L. Machon. Citizenship Through Secondary Geography. London: Routledge/Falmer, 2001.

${ }^{5}$ Bates, D. J. "The Nature and Place of Religion in English State Education c1900c1944 with Special Reference to Conceptions of the Relations of Religion to Education and the Development of Christian Education c1920-c1944." Ph.D. diss., University of Lancaster, 1976; Bates, D. J. “Ecumenism and Religious Education between the Wars: The Work of J. H. Oldham." British Journal of Religious Education 8, no. 3 (1986): 130-139; Michell, C. E. “Christian Education and the Christian Nation: A Study of the Role Envisaged for Religious Education in British State Schools. c1920-1965." M.Litt. diss., University of Cambridge, 1985; Michell, C. E. “Some Themes in Christian Education c.1935-60.” British Journal of Religious Education 6, no. 2 (1984): 82-87; Copley, T. D. "Rediscovering the Past: Writings on Religious Education in Religion in 
Education Quarterly, 1934-39, Raise Some Questions for Today's Religious Educators." British Journal of Religious Education 20, no. 2 (1998): 80-89. ${ }^{6}$ Whitmarsh, G. "Society and the School Curriculum: The Association for Education in Citizenship 1935-57.” M.Ed. diss., University of Birmingham, 1972. Whitmarsh, G. "The Politics of Political Education.” Journal of Curriculum Studies 6, no. 2 (1974): 133-142; Heater, D. Citizenship: The Civic Ideal in World History, Politics and Education. London: Longman, 1990; Heater, D. “The History of Citizenship Education in England." The Curriculum Journal 12, no. 1 (2001): 103-123; Heater, D. A History of Education for Citizenship. London: RoutledgeFalmer, 2004; Wong, Y. Y. J. “Continuity and Change in Citizenship Education in England in the Twentieth Century." Ph.D. diss., University of Liverpool, 1991.

${ }^{7}$ Heater, Citizenship, 31 and 170; Gordon, P. and D. Lawton. Curriculum Change in the Nineteenth and Twentieth Centuries. London: Hodder and Stoughton, 1978: 99-100 and 101-2; Gordon, P. and J. White. Philosophers as Educational Reformers: The Influence of Idealism on British Educational Thought and Practice. London: Routledge and Kegan Paul, 1979: 115; Hilliard, F. H. "The Moral Instruction League 1897-1919.” The Durham Research Review 3, no. 12 (1961): 53-63; Smith, J. T. “The Beginnings of Citizenship Education in England.” History of Education Society Bulletin, no. 69 (May 2002): 6-16, see 10-12; Batho, G. "The History of the Teaching of Civics and Citizenship in English Schools." The Curriculum Journal 1, no. 1 (1990): 91-100.

${ }^{8}$ Lawton, D. and P. Gordon. A History of Western Educational Ideas. London: Woburn Press, 2002: 124-6; Heater, “The History of Citizenship Education in 
England," 118; Kerr, D. Re-examining Citizenship Education: The Case of England. Slough: National Foundation for Education Research, 1999: 4; Marsden, B. “Citizenship Education: Permeation or Pervasion? Some Historical Pointers." In Citizenship Through Secondary Geography, edited by D. Lambert, and L. Machon. London: Routledge/Falmer, 2001: 11-30, see 12-3; Batho, "The History of the Teaching of Civics and Citizenship in English Schools," 94.

${ }^{9}$ Whitmarsh, "Society and the School Curriculum," 19.

${ }^{10}$ b.1795-d.1842, Headmaster of Rugby School, 1827-42.

${ }^{11}$ Copley, T. Black Tom Arnold of Rugby: The Man and The Myth. London:

Continuum, 2002: 120; Copley, T. D. Spiritual Development in the State School: A Perspective on Worship and Spirituality in the Education System of England and Wales. Exeter: University of Exeter Press, 2000: 32.

${ }^{12}$ Brindle, P. and M. Arnot. “'England Expects Every Man to Do His Duty': The Gendering of the Citizenship Textbook, 1940-1966." Oxford Review of Education 25, no. 1/2 (1999): 103-123, see 103 and 119.

${ }^{13}$ Wong, "Continuity and Change in Citizenship Education in England in the Twentieth Century," 43-58; Heater, "The History of Citizenship Education in England," 115; Smith, "The Beginnings of Citizenship Education in England," 1213; Watkins, C. "Inventing International Citizenship: Badminton School and the Progressive Tradition between the Wars." History of Education (Forthcoming). ${ }^{14}$ b.1836-d.1882, Whyte's Professor of Moral Philosophy, Oxford, 1878-1882. Green, T. H. Prolegomena to Ethics. Edited by David. O. Brink. Oxford: Clarendon Press, 2004; Dimova-Cookson, M. and W. J. Mander., eds. T. H. Green: Ethics, Metaphysics, and Political Philosophy. Oxford: Clarendon Press, 2006; British 
Idealist Studies Series 3: Thomas Hill Green, 4 vols. ed. Peter Nicholson. Thorverton: Imprint Academic, 2003-2005.

${ }^{15}$ Myers, K. “National Identity, Citizenship and Education for Displacement: Spanish Refugee Children in Cambridge, 1937." History of Education 28, no. 3 (1999): 313-325, see 320-3.

${ }^{16}$ b.1879-d.1960.

${ }^{17}$ Stocks, M. Ernest Simon of Manchester. Manchester: Manchester University Press, 1963: 91-4; Whitmarsh, "Society and the School Curriculum," 28, 35; Taylor, A. J. P. English History 1914-1945. Harmondsworth: Penguin Books, [1965] (1981): 337.

${ }^{18}$ Whitmarsh, "Society and the School Curriculum," 35.

${ }^{19}$ b.1886-d.1949, Principal of Morley College for Working Men and Women. Hopkinson, D. Family Inheritance: A Life of Eva Hubback. London: New York, Staples Press, 1954.

${ }^{20}$ b.1883-d.1972, member of the Manchester Education Committee and the Board of Education Consultative Committee. Martin, J. 'Shena Simon (18831972) and the 'Religion of Humanity'. In Women and Education, 1800-1980: Educational Change and Personal Identities. J. Martin and J. Goodman. Basingstoke: Palgrave, 2004: 118-140; Martin, J. “Shena D. Simon and English Education Policy: Inside/out?” History of Education 32, no. 5 (2003): 477-84. ${ }^{21}$ Stocks, Ernest Simon of Manchester, 2-3, 18, 20-1, 78. ${ }^{22}$ Simon, E. “The Faith of a Democrat.” The Citizen. 4. (1937): 5-13, see 6. ${ }^{23}$ Ibid., 6 and 11. 
${ }^{24}$ Simon, E. and E. M. Hubback. Training for Citizenship. London: Oxford University Press, 1935: 13.

${ }^{25}$ Stocks, Ernest Simon of Manchester, 106.

${ }^{26}$ Simon and Hubback, Training for Citizenship, 2, 20-21 and 44; Hubback, E. M. "New Ideas For Training in Citizenship." In The Year Book of Education 1936, edited by H. V. Usill. London: Evans Bros, 1936: 528-539, see 528; Pink, M. A. “The Problem of the School Curriculum." The Citizen 2 (1936): 10-11, see 11; Whitmarsh, "Society and the School Curriculum," 47; Wong, "Continuity and Change in Citizenship Education in England in the Twentieth Century," 51-52. ${ }^{27}$ Whitmarsh, "The Politics of Political Education," 135; Board of Education Consultative Committee. Secondary Education with Special Reference to Grammar Schools and Technical High Schools, xxxvii-xxxviii, 160, 163 and 189. ${ }^{28}$ b.1882-d.1962, Master of Corpus Christi College, Cambridge, 1927-52. ${ }^{29}$ b.1867-d.1947, Prime Minister 1923, 1924-9 and 1935-7 and President of the AEC, 1938-1941.

${ }^{30}$ b.1875-d.1956, President of St. John's College, Oxford, 1934-46.

${ }^{31}$ Board of Education. Curriculum and Examinations in Secondary Schools, 58-59 and 100-1.

${ }^{32}$ Myers, "National Identity, Citizenship and Education for Displacement," 323-5. ${ }^{33}$ Tinkler, P. “Youth's Opportunity? The Education Act of 1944 and Proposals for Part-time Continuation Education." History of Education 30, no. 1 (2001): 77-94, see 78.

${ }^{34}$ Grimley, M. "Citizenship, Community and the Church of England: Anglican Theories of the State c1926-1939." Ph.D. diss., University of Oxford, 1998. 
${ }^{35}$ Williamson, P. Stanley Baldwin. Cambridge: Cambridge University Press, 1999: 56.

${ }^{36}$ Hastings, A. A History of English Christianity 1920-1985. London: Collins, 1986: 290; Lowndes, G. A. N. The Silent Social Revolution. London: Oxford University Press, 1970: 259; Baker, A. E. William Temple and His Message. Harmondsworth: Penguin Books, 1946: 202; Reeves, M. (Ed.). Christian Thinking and Social Order. London: Cassell, 1999.

${ }^{37}$ b.1881-d.1944, Archbishop of York, 1929-42 and Archbishop of Canterbury, 1942-44.

${ }^{38}$ The Moot was a private discussion group founded by J. H. Oldham (b.1874d.1969, Secretary of the International Missionary Council, 1921-38). Between 1938 and 1947 it promoted the involvement of Christian intellectuals in planning post-war reconstruction. Participants included T. S. Eliot (b.1888-d.1965, poet, dramatist, critic and publisher), Karl Mannheim (b.1893-d.1947, Lecturer in Sociology, London School of Economics, 1933-45), Fred Clarke (b.1880-d.1952, Director of the Institute of Education, London, 1936-45) and R. H. Tawney (b.1880-d.1962, Professor of Economic History, London School of Economics, 1931-49).

${ }^{39}$ Chadwick, P. Shifting Alliances: Church and State in English Education. London: Cassell, 1997: 26.

${ }^{40}$ Bates, "The Nature and Place of Religion in English State Education c1900c1944."

${ }^{41}$ Copley, Spiritual Development in the State School, 61. 
${ }^{42}$ Bates, "The Nature and Place of Religion in English State Education c1900c1944," 34.

${ }^{43}$ Michell, "Christian Education and the Christian Nation," 50-1, 81-2, 85, 115 and 263; Michell, "Some Themes in Christian Education c.1935-60," 85. ${ }^{44}$ Bates, "The Nature and Place of Religion in English State Education c1900c1944."

${ }^{45}$ Bates, "Ecumenism and Religious Education between the Wars," 136-7.

${ }^{46}$ Oldham was referring to the Internationalism of the League of Nations as promoted by the English writer H. G. Wells (b.1866-d.1946).

${ }^{47}$ Oldham, J. H. "Education for an International World." Religion in Education 1, no. 3 (1934): 123-36, see 135-6.

${ }^{48}$ Bates, "Ecumenism and Religious Education between the Wars," 135-6.

${ }^{49}$ Oldham, J. H. Religious Education: A Preliminary Paper to Serve as a Starting Point for Discussion by Groups. London: International Missionary Council. 1927: 24.

${ }^{50}$ Reeves, Christian Thinking and Social Order, 69.

${ }^{51}$ b.1881-d.1959, President of the Board of Education, 1932-35.

${ }^{52}$ Irwin, Lord. "Education and Religion.” Religion in Education 1, no. 1 (1934): 47 , see 5 .

${ }^{53}$ b.1883-d.1967, Reader in Educational Psychology, Oxford University, 1935-49.

${ }^{54}$ Yeaxlee, B. “Liberties and Values." Religion in Education 7, no. 2 (1940): 62.

${ }^{55}$ Mitchell, W. F. “The New German Religion and its Implications for Religious Education." Religion in Education 4, no. 1 (1937): 22-29 and Handford, B. W. T. “'Revolutionising' our New Testament Teaching." Religion in Education 4, no. 2 
(1937): 88-94.

${ }^{56}$ Brindle and Arnot, "'England Expects Every Man to Do His Duty': The Gendering of the Citizenship Textbook, 1940-1966," 103.

${ }^{57}$ b.1896-d.1963.

${ }^{58}$ Happold, F. C., W. F. Hoyland, B. L. Deed, C. H. C. Sharp, C. H. Dobinson, R. Frampton, and K. Hahn. Experiments in Practical Training for Citizenship. No. 5. London: AEC, c1937: 3-4.

${ }^{59}$ Ibid., 3-4.

${ }^{60}$ b.1874-d.1952, Headmistress of Clifton High School, 1908-33 and President of the Association of Headmistresses, 1929-31.

${ }^{61}$ Phillips, A. E. “Training for Citizenship Through Religious Instruction.” The Citizen, no. 5 (1937): 8-9, see 8.

${ }^{62}$ Ibid., 8-9.

${ }^{63}$ b.1904-d.1974, local authority education officer for Kent and the Isle of Wight. ${ }^{64}$ Hutchinson, A. L. "The Aims for Education in Citizenship." In Education for Citizenship in Elementary Schools, Association for Education in Citizenship, London: Oxford University Press, 1939: 3-4.

${ }^{65}$ b.1880-d.1975, Principal of Hull Municipal Training College, 1919-39.

${ }^{66}$ Cumberbirch, C. T. "Moral and Religious Education for Citizenship." In Education for Citizenship in Elementary Schools, Association for Education in Citizenship, London: Oxford University Press, 1939, 40-56, see 47. ${ }^{67}$ Ibid., 51.

${ }^{68}$ b.1892-d.1956, Headmaster of Winchester College, 1935-46, and Chairman of the Headmasters' Conference, 1939-45. 
${ }^{69}$ Whitmarsh, "Society and the School Curriculum," 102.

${ }^{70}$ Leeson, S. “Christianity and Citizenship.” Religion in Education 4, no. 1 (1937):

9-13, 9.

${ }^{71}$ Leeson, S. Education in Citizenship. London: Association for Education in Citizenship, 1935: 4-5 and 11.

${ }^{72}$ Leeson, "Christianity and Citizenship," 10.

${ }^{73}$ Leeson, S. Christian Education. London: Longmans, 1948: 47.

${ }^{74}$ Leeson, "Christianity and Citizenship," 12; and Leeson, Christian Education, 49.

${ }^{75}$ Leeson, “Christianity and Citizenship,” 13.

${ }^{76}$ Leeson, S. The Public Schools Question and Other Essays on Subjects Connected with Secondary Education. London: Longmans, 1948: 80-83 and 94.

${ }^{77}$ Leeson, Christian Education, 137-8.

${ }^{78}$ Bates, "The Nature and Place of Religion in English State Education c1900c1944," 113.

${ }^{79}$ b.1900-d.1985, Professor of Education at the University of Durham, 1939-45. ${ }^{80}$ Jeffreys, M. V. C. “Some Suggestions Towards a Modern Christian View of Education." Religion in Education 7, no. 4 (1940): 185-194, see 191 and 193-4. ${ }^{81}$ Ibid., 193-4.

${ }^{82}$ Jeffreys, M. V. C. “Some Suggestions Towards a Modern Christian View of Education." Religion in Education 8, no. 1 (1941): 29-35, see 31 and 33-5.

${ }^{83}$ b.1907-d.2003, Fellow at St Anne's College, Oxford, 1938-74.

${ }^{84}$ Reeves, Christian Thinking and Social Order, 120. 
${ }^{85}$ Bates, "The Nature and Place of Religion in English State Education c1900c1944," 234.

${ }^{86}$ b.1894-d.1964, Director of the Department of Education, Oxford University, 1937-57.

${ }^{87}$ Jacks, M. L. “Total Education.” The Hibbert Journal 42, no. 1 (1943): 26-30, see 27.

${ }^{88}$ b.1868-d.1955, Minister of the Old Meeting Church, Birmingham.

${ }^{89}$ Lloyd Thomas, J. M. “Compulsory Christianity.” The Hibbert Journal 42, no. 3 (1944): 220-226, see 223.

${ }^{90}$ Ibid., 225.

${ }^{91}$ b.1894-d.1961. Head of Department of Divinity, King's College, University of Durham.

${ }^{92}$ Allen, E. L. "The Roots of Democracy in the Old Testament." Religion in Education 7, no. 3 (1940): 146-151, see 146.

${ }^{93}$ b.1880-d.1956, examining chaplain to the Bishop of Salisbury, 1932-46.

${ }^{94}$ Prideaux, S. P. T. “The Bible as a Handbook of Citizenship.” Religion in Education 7, no. 4 (1940): 203-209, see 204 and 208.

${ }^{95}$ b.1871-d.1957, Fellow and tutor of Balliol College, Oxford.

${ }^{96}$ Bailey, C. "The Schools and Christian Democracy." Religion in Education 7, no. 2 (1940): 80-83, see 81 and 83.

${ }^{97}$ b.1893-d.1986, Headmaster of Rugby, 1931-48.

${ }^{98}$ Lyon, H. "The Spiritual Basis of World Citizenship." Religion in Education 7, no. 3 (1940): 126-132, see 126, 129 and 131-2.

${ }^{99}$ b.1880-d.1958, General Secretary of the League of Nations Union, 1920-38. 
${ }^{100}$ Bates, "The Nature and Place of Religion in English State Education c1900c1944," 134-5.

${ }^{101}$ Garnett, M. "Religion as the Unifying Principle in Education and Citizenship." The Hibbert Journal 41, no. 2 (1943): 241-49, see 242.

${ }^{102}$ Garnett, M. “Nazis or Christians: a Problem of Education.” Religion in Education 8, no. 1 (1941): 9-16, see 14.

${ }^{103}$ b.1824-d.1903, Chief Inspector of Training Colleges.

${ }^{104}$ Copley, Black Tom Arnold of Rugby, 2.

${ }^{105}$ b.1822-d.1896.

${ }^{106}$ Bates, "The Nature and Place of Religion in English State Education c1900c1944," 84.

${ }^{107}$ Michell, "Christian Education and the Christian Nation," 277.

${ }^{108}$ Board of Education Consultative Committee. A Conference held at the Board of Education on November $30^{\text {th }} 1933$ and March $20^{\text {th }} 1934$ on the Provision of Improved Opportunities for Teachers to Equip themselves for giving Religious Instruction, London: HMSO, 1934.

${ }^{109}$ Board of Education. Curriculum and Examinations in Secondary Schools, 208. ${ }^{110}$ Board of Education. Curriculum and Examinations in Secondary Schools, 84-5 and 87-9.

${ }^{111}$ Cannon, C. “The Influence of Religion on Educational Policy, 1902-1944.” The British Journal of Educational Studies 12, no. 2 (1964): 143-160, see 150.

${ }^{112}$ Behenna, M. “The Significance of Canon E. F. Hall as General Secretary of the National Society in the Negotiations between the Church of England and the Government on the Clauses of the 1944 Education Act Concerning 
Denominational Religious Education and Church Schools.” M.Phil. diss., University of Exeter, 2001: 125.

${ }^{113}$ Michell, "Christian Education and the Christian Nation," 48.

${ }^{114}$ Copley, Teaching Religion, 33-5; Michell, “Christian Education and the Christian Nation," 163-4.

${ }^{115}$ Myers, "National Identity, Citizenship and Education for Displacement," 323-4. ${ }^{116}$ Brindle and Arnot, “'England Expects Every Man to Do His Duty': The Gendering of the Citizenship Textbook, 1940-1966," 120.

${ }^{117}$ Lowe, R. Education in the Post-war Years: A Social History. London: Routledge, 1988: 18.

${ }^{118}$ Ministry of Education. Pamphlet No. 16: Citizens Growing Up. London: HMSO, 1949: 7.

${ }^{119}$ Whitmarsh, "Society and the School Curriculum", 150.

${ }^{120}$ Ministry of Education, Citizens Growing Up, 10 and 18-19.

${ }^{121}$ Ibid., 11.

${ }^{122}$ Myers, “National Identity, Citizenship and Education for Displacement," 325.

${ }^{123}$ Ministry of Education, Citizens Growing Up, 11-13, 15-16, 37 and 45. ${ }^{124}$ Ibid., 52.

${ }^{125}$ Brindle and Arnot, “'England Expects Every Man to Do His Duty': The Gendering of the Citizenship Textbook, 1940-1966," 105.

${ }^{126}$ Qualifications and Curriculum Authority. Citizenship: The National Curriculum for England and Wales. London: Qualification and Curriculum Authority, 1999; and Qualifications and Curriculum Authority. Citizenship at Key Stage 3 and 4. London: Qualification and Curriculum Authority, 2000. 
${ }^{127}$ Kerr, Re-examining Citizenship Education, 4.

${ }^{128}$ Ibid., 10-11. 